\title{
Women Accused of Homicide: The Impact of Race, Relationship to Victim, and Prior Physical Abuse
}

\author{
Carolyn Field', Suvarna Cherukuri'2, Sitawa R. Kimuna ${ }^{3}$, Dee Berg1 \\ ${ }^{1}$ Social Science Department, Edgewood College, Madison, WI, USA \\ ${ }^{2}$ Sociology Department, Siena College, Loudonville, NY, USA \\ ${ }^{3}$ East Carolina University, Greenville, NC, USA \\ Email: cfield@edgewood.edu, scherukuri@siena.edu, kimunas@ecu.edu,dberg@edgewood.edu
}

How to cite this paper: Field, C., Cherukuri, S., Kimuna, S. R., \& Berg, D. (2017). Women Accused of Homicide: The Impact of Race, Relationship to Victim, and Prior Physical Abuse. Advances in Applied Sociology, 7, 281-304.

https://doi.org/10.4236/aasoci.2017.78018

Received: July 12, 2017

Accepted: August 8, 2017

Published: August 11, 2017

Copyright (c) 2017 by authors and Scientific Research Publishing Inc. This work is licensed under the Creative Commons Attribution International License (CC BY 4.0). http://creativecommons.org/licenses/by/4.0/

\begin{abstract}
This study analyzes data collected from a Public Defender's office in a Mid-Atlantic city, which represents females accused of homicide $(\mathrm{N}=48)$ and defended between the years 1994-2011. Further, this study includes qualitative interviews of the Public Defenders who work in the Homicide Division of this jurisdiction and who defended the women accused of these murders in the courts. Results show that most cases involved intra-racial homicides of current or former intimate partners. Women who killed a boyfriend or husband and women who were diagnosed with battered woman syndrome (BWS) received lighter sentences. Interviews with Public Defenders highlighted the importance of the relationship between victims and offenders in the handling of homicide cases by the court.
\end{abstract}

\section{Keywords}

Homicide, Battered Woman Syndrome, Intimate Partner Violence, Physical Abuse, Sexual Abuse, Public Defender

\section{Introduction}

This study analyzes variation in the responses of the criminal justice system to cases of female perpetrated homicide. Race, sex, age, relationship to victim, background of abuse and psychological state of the perpetrator are the main variables used to explain the patterns of criminal court response. The awareness that female homicides are often rooted in a deeper victimhood has led to increased scrutiny of the response of the criminal justice system to such cases. This 
study continues this scrutiny by applying the Blackian theory of law to data on female perpetrated homicides collected from a Public Defender's office in a large mid-Atlantic city in the United States $(\mathrm{N}=48)$. In doing so, we argue that Donald Black's propositions on the relationship between law and social distance can be used by feminist research to explain the sentencing patterns in intimate partner homicides overall, and homicides wherein battered woman's syndrome may be an issue of importance in some way.

An influential strain of evidence suggests that a number of female perpetrated homicides in the United States are related in multiple ways to biological sex and gender roles, and are often committed as self-defense or retaliation for ongoing intimate partner abuse (Gange, 1998). Several studies have found that women accused of killing their abusive partners are usually convicted of some degree of murder or accept a plea bargain and that both outcomes often lead to lengthy prison sentences (Belknap, 2000; Gange, 1998; O’Keefe, 1997; Roberts, 1996). Yet, these studies do not control for the overall level of punitiveness regarding women who kill in other circumstances in that community. A pattern of harsh sentences for battered women who kill in these jurisdictions may reflect an overall conservative and punitive tradition in that particular court, regardless of who killed whom or the circumstances surrounding the event. In other words, some areas are more politically conservative than others, and therefore some courtroom workgroups (the judges, prosecutors, defense attorneys and others who work together regularly in a particular court jurisdiction) may be more punitive than others towards all crimes or certain kinds of crime (Hephner, 2002; Knepper \& Barton, 1997). For this reason, data is needed that allows the comparison of legal outcomes for cases involving battered women versus female homicide defendant cases that did not involve the slaying of an allegedly abusive partner. This research seeks to fill the void in understanding women who kill by examining the contexts of their crimes including their relationship to the victim of their violence, their psychological and social histories prior to and during the time of the crime, and the impact of important demographic variables, such as age and race, on the way their case is viewed and handled by the law. Through a thorough examination of an original sample of quantitative data, combined with explanations of the behavior of law straight from the very Defense Attorneys who took on these cases, this research seeks to add nuance to our social scientific understanding of female homicidal behavior and bring to light the impacts of physical and sexual victimization on subsequent female criminal behavior which has been noted by feminist scholars, but often ignored, for decades.

\section{Literature Review}

\subsection{Women and Violent Crime}

Crime in general, and homicides in particular, have historically been explained through the lens of masculinity and male essentialism. Polk (1994) sees an indisputable relation between homicidal violence and masculinity. Young (1996: 
27) notes that the question of femininity has, "in many ways been criminology's best kept secret". Men and their criminality became the logical starting point for the discipline. This unidirectional gaze has led to the establishment of blatant sexism in making sense of women's offenses. The deterministic fervor of these explanations masks a number of factors that condition human behavior. Ironically, the fallacy of determinism inherent in these theories is exposed in their attempt to typify female criminality.

Feminist analysis on intimate partner homicide addresses the intersection between biological sex and gender roles, power, and violence deeply rooted in patriarchal institutions like family and marriage. "Studies of women who kill violent partners have led to the development of a concept known as 'battered woman syndrome' which has been popular both as a theory of women's homicide and as a legal tool used in conjunction with defenses to murder" (Kirkwood, 2003: 3). Kirkwood (2003) shows that the lack of knowledge and understanding of women who kill results in a situation where women who do kill are highly stigmatized. They are what Heidensohn (1985) and Lloyd (1995) refer to as "doubly deviant and doubly damned" (cited in Kirkwood, 2003: 3).

Feminist explanations often situate female perpetrated homicides in the context of reactions to abuse by their partners (Bannister, 1991; Browne, 1987; DeKeseredy \& Hinch, 1991; Easteal, 1993; Ewing, 1987; Gillespie, 1989; Goetting, 1987; Shaw \& Dubois, 1995; Walker, 1989). It has long been argued that women perpetrate homicides mainly in self-defense, to either protect themselves or their children; in addition, these women do not have prior criminal history and before taking the extreme step they usually have tried to reach out to the criminal justice system (Browne, 1987).

Many empirical studies document the background of abuse that is intertwined with female perpetrated homicides of partners (Campbell, 1992; Chimbos, 1976; Polk, 1994; Totman, 1978; Walker, 2006). Chimbos (1976) found in police records that most Canadian women who had killed their partner were abused. Totman's (1978) study showed that 29 of the 30 women interviewed in a California State Prison had been abused; Campbell (1992) and Polk (1994) also reported similar findings. Studies have clearly shown that battering is a reflection of a deeply embedded power equation in the relationship and coercive instrument often supported by the culture of male dominance and patriarchy (Goetting, 1999). Osthoff (1991) documented that approximately $80 \%$ of the women who have been accused of killing their partner are convicted. These women either take the plea or serve long sentences (Osthoff, 1991).

Little research has been done on what happens to women in the United States criminal justice system who admit they have killed their intimate or ex-partner but who claim they did so in self-defense (or a perception that they were in imminent danger at the time of their homicidal action). In the most extreme cases of partner violence that ends in the death of the male, the defense cites the battered woman's syndrome (BWS), which a subcategory of post-traumatic disorder (PTSD), similar to the reactions of veterans who have witnessed great trauma 
in war (Walker, 2006). More specifically, BWS is described as a state of psychological dismay in which a woman suffers from extreme fear, nervousness, a sense of helplessness or loss of efficacy in her daily life and distorted perceptions as to her personal safety as a result of a history of serial physical, psychological and/or sexual abuse at the hands of an intimate partner (Browne, 1987; Leonard, 2002). Research indicates that when women kill an abusive partner as a result of BWS, they usually call the police immediately and readily admit to having committed the murder as opposed to running, hiding or denying the action as men tend to do when they kill a partner (Browne, 1987; Leonard, 2002). In other words, when women kill a partner, or ex-partner, they are usually under some kind of duress at the time, whether real or perceived, and therefore readily admit to what they have done when police arrive at the scene.

Many studies over the past several decades have examined the issue of battered women who killed their abusive partners by interviewing convicted women or gaining access to prison data, but there are many impediments to the task of truly estimating how many women are actually in prison today as a result of battery cases that ended in homicide (Browne, 1987; Hadley, 1992; Leonard, 2001, 2002; Roberts, 1996). These studies focus on the characteristics of the women who killed their partners and the circumstances that led up to the homicides. The focus of these studies is largely the experience of BWS for the women, yet there is little information regarding the use of this psychological state as a defense tactic and its efficacy in the courts. Further, these studies only include those women who actually ended up serving prison time for the slaying of an abusive partner: other than Browne's (1987) groundbreaking qualitative research in When Battered Women Kill, the data from other and more recent studies does not include those women who do not go to prison even though they may have readily admitted to slaying their abusive partner. Studies which examined battered women who killed from a prison sample end up missing those defendants who did not end up in prison after the fatal incident. Browne's (1987) study does provide some data on this issue as she reported that $56 \%$ of the women in her small sample of battered women who killed their abusive male partners argued their cases on the basis of self-defense, while 33\% plea-bargained, and $8 \%$ pleadnot guilty due to insanity (citing battered woman syndrome as the cause).

\subsection{Theoretical Perspective}

In this study, we use Donald Black's Theory of Law to examine the legal outcomes of female perpetrated homicides. Donald Black's Theory of Law explains variation in police behavior and the application of criminal law across various social settings. According to the theory, the quantity of law (i.e., the activation of a response from the legal system) varies depending on the social facts involved in the case (Black, 1989). For this "pure sociology" perspective, the behavior of the legal system is the unit of analysis, not the behavior of the individual. Each increment of legal action represents an increase in the "quantity of law". 
For example, a reported crime represents more law than an unreported crime, an investigation is more law than a report alone, an arrest is more law than a simple warning, and an arrest, conviction, and imprisonment (or the death penalty) represent the largest quantities of law that could be applied to a criminal case. From Black's perspective, the quantity of law depends on more than just the seriousness of the offense. It also depends on the social structure of the case, or the social and demographic variables of importance such as the status of the parties involved, the level of intimacy or familiarity between the parties involved, or social variables deemed relevant to the culture such as the race, class, or biological sex and gender roles of the parties involved in the legal case. "In a modern society such as the United States, the social structure of the complaint itself may be the most important predictor of how a case will be handled" (Black, 1989: 9). The social status of the parties involved factor into the handling of the legal or criminal cases so that if the victim is of higher social status than the perpetrator, one can expect more law to be applied to the case than if the social status difference were the other way around. From Black's perspective then, biological sex, income, employment status, race and other social factors can also be considered aspects of social status in the United States today. We extend Black's (1976) examination of the law and social status to strengthen the intersectional feminist understanding of the criminal justice system. This gives a better insight on how race, class, biological sex and women's relationships with their victims impact the outcome of sentencing. Specifically, it is likely that more law will be applied to cases involving defendants with law social status or social integration. Based on Black's (1976: 21) structural quantity of stratification and his proposition that "Law of every kind is more likely to have a downward direction than an upward direction", we hypothesized:

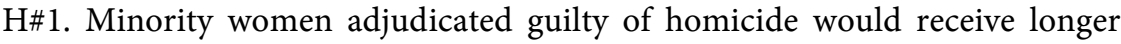
sentences than Whites.

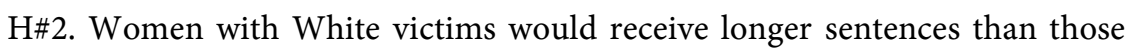
with Minority victims. We expect that since minority women have historically faced legal hurdles in negotiating race, gender, and class, they will receive longer sentences than White women adjudicated guilty of the same offense.

Further, Black's theory suggests that social morphology or the structure and patterns of interpersonal association and connection are main predictors of legal variation in the amount of law applied to one case versus another. The theory argues that two elements of morphology predict the quantity of law: 1) the degree of social integration amongst the offender and victim of the crime and 2) the strength of the relationship between the victim and the offender. With regards to social integration, the theory suggests that the law may be applied more harshly to a female defendant who is seen as having no social connections in the view of the courtroom workgroup (or jury if that applies). A prostitute, for instance, may be seen as less socially tied to society, whereas a housewife may be seen in another light. In fact, Black's theory of law suggests that the more social information is known to the members of the courtroom workgroup (such as the 
occupation, race, biological sex, age of the defendant), the more discrimination can take place in the handling of the case and a more disadvantaged group is likely to have more law applied to their cases.

Kruttschnitt (1982) situated her research on the impact of economic dependency of the woman and her social location on criminal prosecution in Black's (1976: 508) understanding of law. She found support for her hypothesized relationship between economic dependency and severity, especially in cases of petty theft offenders and forgers. Independent women received more severe dispositions than those who were located in the social life. "The freer woman lacked daily supervision and, hence, in the probation officer's eyes, her living situation necessitated the formal controls of a probationary period in addition to the harsh sentence of one year in the county jail. By contrast, the woman whose life is encompassed by family ties receives neither the jail term nor the supervisions of formal probation."

Black asserts that the strength of the bond, or the extent of intimacy in the relationship between victim and offender, is of utmost importance to understanding the behavior of law. Relational ties between victim and perpetrator and the social characteristics of both parties contribute to the decisions made by the courts about how much law to apply to each case. Those cases between intimates tend to attract less law. Crimes against strangers tend to attract more criminal justice and court response. Black (1976) suggests that the closer the relationship between the victim and offender, the less law tends to be applied to the case. For instance, a husband hits a wife, the wife does not call the police, the children witness the crime, but nobody calls the authorities. This common scenario represents the least amount of law that could be applied to this hypothetical partner assault. Black suggests that when crimes are committed against strangers, law is more likely to be applied to its fullest extent. If a woman were to be assaulted by a complete stranger, she might be more likely to call the police. Dawson (2006) examined the role of victim-offender relationships in the criminal processing of Toronto homicides over the period 1974-1996. She found that offenders whose victims were relatives or intimate partners received less severe sentences than offenders who killed strangers, friends, or acquaintances (cited in Auerhahn, 2006: 282). Dawson's (2006) study found similar results, wherein defendants who killed intimate partners received shorter sentences than defendants whose victims were not intimate partners. We therefore further hypothesize:

$\mathrm{H \# 3.} \mathrm{Women} \mathrm{found} \mathrm{guilty} \mathrm{of} \mathrm{killing} \mathrm{an} \mathrm{intimate} \mathrm{partner} \mathrm{receive} \mathrm{a} \mathrm{lighter} \mathrm{sen-}$ tence than those adjudicated guilty for killing strangers or others.

Feminist research suggests that the power differentials in relationships within the context of a patriarchal society contribute to female perpetrated homicides against their intimate partners in self-defense scenarios. The courts in the Mid-Atlantic city used for this study take into account pleas of self-defense and use of the BWS as a mitigating explanation for women accused of this kind of partner homicide. Therefore, this study also examines the following hypotheses: 
$\mathrm{H \# 4.} \mathrm{Women} \mathrm{found} \mathrm{guilty} \mathrm{of} \mathrm{killing} \mathrm{their} \mathrm{intimate} \mathrm{partner} \mathrm{and} \mathrm{diagnosed} \mathrm{with}$ BWS would receive lower sentences than those women accused of homicide in other circumstances or without such a diagnosis.

H\#5. Women who were physically abused by the homicide victim prior to the fatal incident would receive lower sentences than those who had no history of prior abuse by the homicide victim.

\section{Data and Method}

\subsection{Data Collection}

Quantitative Data Collection. Data on the homicide cases was collected by the first author with formal academic institutional approval ${ }^{1}$, and with approval from the Chief Public Defender of the jurisdiction. The Chief Public Defender gave consent to the data collection with certain protections put in place to protect the identities of the female homicide defendant clients handled by the office. First, the name of the city the data came from was required to remain anonymous; second, only the Public Defenders could read and physically handle the defendant's files; and third, the names of defendants and victims were not to be included in the data collection. Lastly, the Chief Public Defender of the jurisdiction required that no particular cases would be described in detail in publications or public presentations in a manner which would allow identification of the defendant, their victim(s), or the specific crime. The Chief Attorney of the Homicide Division assisted the first author in the data collection process on numerous visits by the first author to the Public Defender's Office for both data collection waves. For the information on the female client's cases, the Chief of the Homicide Division or another available Defense Attorney went through each file as the first author compiled information on the variables of interest on data collection sheets. The first author then took these sheets and the variables were coded into numeric form in SPSS for analysis. For the Qualitative Interviews, the Chief Homicide Defense Attorney assisted the first author in scheduling and they were completed in private with each respondent and digitally recorded (one was completed over the phone and the Attorney refused to be recorded, so detailed notes and quotes were taken down by the first author for this interview).

As a matter of procedure, an expert Forensic Psychiatrist who specializes in the areas of female crime and BWS gave almost all female homicide defendants a full psychiatric evaluation. The only clients who were not evaluated in such a manner were the ones who refused to speak with the Forensic Psychiatrist.

Data on the criminal histories of the women accused of homicide was easily available since a copy of their police record was also included in every defendant's defense attorney file. Yet, collecting data on the personal histories of the women accused of homicide required more effort since evidence of abuse, pre-

${ }^{1}$ Data collection was competed in two waves (2009 and 2012): the second wave included more recently completed female homicide defendant cases as well as Qualitative Interviews with the Public Defender's Office employees. The first wave of data collection was with IRB approval from Elizabethtown College, the first author's host institution at that time. The second wave of data collection was approved by Edgewood College, the first author's current host institution. 
vious criminal victimization, etc. was possible to find in several places in the defense attorney files. Primarily, evidence of interpersonal histories of the female homicide defendants was located in one or more of four possible sources: 1) the Police Report of the crime, 2) Police Report of the Defendant's Criminal History (prior arrests and/or convictions), 3) the Forensic Psychiatrist's Report commissioned by the Public Defender's Office upon arrest of every homicide defendant, and 4) the Mitigation Specialist's Report. Mitigation Specialists are full time Public Defense Office employees who are responsible for constructing a Mitigation Report, which summarizes the personal history of each defendant and puts the crime they have been accused of, or admitted to, into a larger social and psychological context. For instance, in order to validate abuse and/or neglect claims from childhood that the defendant may have made during her examination by the Forensic Psychiatrist, the Mitigation Specialists call, or interview in person, the defendant's family, friends, childhood neighbors, grade school, middle school, and high school teachers, and/or anyone else who has known or had contact with the defendant during their childhood. Specifically, the Mitigation Specialist looks to strengthen the Defense Attorney's case by locating individuals from the Defendant's past who can testify to childhood trauma or other mitigating circumstances which would help in the client's defense, or at least put their actions in a more understandable context. The data was first divided into the broad categories of crime context, defendant characteristics, homicide victim characteristics, and legal outcomes, and then coded into further sub-categories to obtain the relevant variables.

Qualitative Data Collection. In 2012 the first author returned to the Homicide Division several times to collect qualitative data from the Defense Attorneys themselves regarding their perceptions of their female clients and the strategies with which they approach these rare homicide cases with female defendants. In the Homicide Division there were 12 Defense Attorneys employed at the time of the interviews. Seven of the Defense Attorneys were available and willing to be interviewed, and as mentioned earlier, all but one was willing to let their interviews be digitally recorded for later transcription. Lastly, one of the Mitigation Specialists was also willing to be interviewed, while the other Specialist declined participation in the study, saying she was worried about divulging confidential information about her clients during the process.

\subsection{Crime Context}

Crime scene situation. The situation at the time of homicide was divided into the following eight categories: 1) a domestic incident, 2) during the commission of another crime, 3) a drug-induced rage, 4) accessory to a homicide, 5) during an altercation, 6) during an attempted sexual assault, 7) during parenting, and 8) a random act of violence.

Victim's cause of death. Cause of death was coded into the following five categories: 1) stabbing, 2) gunshot, 3) strangulation, 4) poisoning, and 5) other. 
BWS. A variable was collected to indicate whether or not the defendant was diagnosed with battered woman's syndrome (BWS). It is important to note that the Forensic Psychiatrist used by this Public Defender's office for these evaluations routinely wrote and testified to the formal diagnosis of PTSD, even when her psychiatric report also indicated "classic symptoms of BWS." In this way, it seems that the Forensic Psychiatrist viewed these as interchangeable disorders in her diagnoses of these women.

\subsection{Female Homicide Defendants}

Age. The age of each homicide defendant was recorded in years. Age was also categorized in the following manner for the chi-square tests of significance: 1) 11 - 16, 2) 17 - 21, 3) 22 - 29, 4) 30 - 40, 5) 41 - 50, 6) 51 - 60, and 7) 61 - 80 years old.

Race. The racial identity of each defendant was coded in the following manner: White, African American, Hispanic, Asian, or Other.

Criminal history. Three measures of the female homicide defendant's criminal history were recorded: 1) previous arrests, 2) previous criminal convictions, or 3) previous criminal convictions for a violent offense, with each recorded as "yes" or "no" (with no further details of their previous arrests, charges, or convictions recorded).

History of abuse. Information on each homicide defendant's past was collected from one or several of the following: 1) the Police Report of the crime, 2) Police Report of the Defendant's Criminal History (prior arrests and/or convictions), 3) the Forensic Psychiatrist's Report commissioned by the Public Defender's Office upon arrest of every homicide defendant, or 4) the Mitigation Specialist's Report. Using these sources of information on each defendant, variables were collected regarding whether or not the defendant had ever been the victim of: 1) childhood physical abuse, 2) childhood sexual abuse (including rape), or 3) physical abuse at the hands of the victim of the homicide.

Relationship to victim. The relationship of the female homicide defendant to her alleged victim was recorded and was coded in the following five categories: 1) boyfriend or husband, 2) ex-boyfriend or ex-husband, 3) friend or acquaintance, 4) child, 5) stranger, and 6) other family member.

\subsection{The Homicide Victims}

Victim characteristics. The biological sex, age and race of the victim of each homicide was recorded with the same categories used for the defendants.

\subsection{Legal Outcomes of the Cases}

Court proceedings. The court proceeding was coded in the following six categories: 1) open plea bargain, 2) negotiated plea bargain, 3) degree of guilt hearing, 4) bench trial, 5) jury trial, and 6) charges dropped.

Adjudication. Adjudication was coded as either guilty, not guilty or charges 
dropped.

Sentence. The sentence received by the defendants who were adjudicated guilty, plead guilty, or plea bargained guilty to a homicide charge was coded in the following six categories: 1) no sentence given, 2) time served, 3) time served plus probation, 4) 11 - 36 months in prison, 5) 3 - 40 years in prison, and 6) life in prison. Although this particular state does have capital punishment, no capital sentence has as of yet been received by any of the female defendants handled by this office.

\section{Results}

\section{Quantitative Data Analysis}

Table 1 presents descriptive statistics for the scene of the crime and important legal aspects of the criminal cases examined.

Crime scene situation. For the 48 cases examined, $31 \%$ of the homicides occurred during a domestic violence incident, $23 \%$ occurred during the commission of another crime, $6 \%$ happened as a result of a drug induced rage, $8 \%$ were accessories to a homicide that somebody else committed (in many states this is known as "felony homicide" where anyone committing a felony with someone who kills a person in that incident is also charged with the death of that victim), $13 \%$ occurred during an altercation, $6 \%$ occurred during an attempted sexual assault, $6 \%$ involved a mother killing her own child during the course of parenting, and $6 \%$ were random acts of violence.

Victim's cause of death. An analysis of the cause of death for each homicide victim revealed the following: $48 \%$ died as a result of a stabbing; $25 \%$ died from a gunshot wound; $27 \%$ died from something other than the categories listed above. The "other" category included scenarios such as a woman who pushed her boyfriend down the stairs while he was physically assaulting her. He later died in the hospital as the result of injuries caused by this fall. Another situation was a mother who was accused of smothering her 6-month-old son. During the trial, an expert testified that the infant had actually died as a result of the resuscitative efforts of the ambulance technicians. The mother ended up being acquitted of the murder charges. None of the homicide victims died as a result of strangulation or poisoning.

Plea. Thirty three percent of the defendants entered a "not guilty" plea, while $58 \%$ plead guilty to the charges. Four of the defendants had the charges against them dropped at some point in the process. A point worth emphasizing here is that all but 1 of the women in this data set admitted to committing the offense, or being involved with the crime, for which she was arrested. Only 1 woman included in this data set declared actual innocence, and the Forensic Medical Examiner's report confirmed that she was not guilty of the murder of her infant as the Prosecutors had alleged, so the charges against her were dropped. The only reason that some of the other women pled "not guilty" was that they did not want to admit to the degree of homicide (such as first degree which means a 
Table 1. Descriptive Statistics for Homicide Cases.

\begin{tabular}{|c|c|c|}
\hline Variables & $\mathbf{N}$ & Percent \\
\hline \multicolumn{3}{|l|}{ Crime Scene Situation } \\
\hline Domestic Fight & 15 & 31.3 \\
\hline Commission of Another Crime & 11 & 22.9 \\
\hline Drug-Induced Rage & 3 & 6.3 \\
\hline Accessory to a Homicide & 4 & 8.3 \\
\hline Altercation & 6 & 12.5 \\
\hline Victim of Attempted Sexual Assault & 3 & 6.3 \\
\hline Parenting & 3 & 6.3 \\
\hline Random Act of Violence & 3 & 6.3 \\
\hline Total & 48 & 100.0 \\
\hline \multicolumn{3}{|l|}{ Cause of Death } \\
\hline Stabbing & 23 & 47.9 \\
\hline Gunshot & 12 & 25.0 \\
\hline Strangulation & 0 & -- \\
\hline Poisoning & 0 & -- \\
\hline Other & 13 & 27.1 \\
\hline Total & 48 & 100.0 \\
\hline \multicolumn{3}{|l|}{ Plea } \\
\hline Charges Dropped & 4 & 8.3 \\
\hline Not Guilty & 16 & 33.3 \\
\hline Guilty & 28 & 58.3 \\
\hline Total & 48 & 100.0 \\
\hline \multicolumn{3}{|l|}{ Court Proceedings } \\
\hline Open Plea Bargain & 6 & 12.5 \\
\hline Negotiated Plea Bargain & 16 & 33.3 \\
\hline Degree of Guilt Hearing & 8 & 16.7 \\
\hline Waiver (Bench) Trial & 13 & 27.1 \\
\hline Jury Trial & 3 & 6.3 \\
\hline Charges Dropped & 2 & 4.2 \\
\hline Total & 48 & 100.0 \\
\hline \multicolumn{3}{|l|}{ Adjudication } \\
\hline Charges Dropped & 4 & 8.3 \\
\hline Not Guilty & 5 & 10.4 \\
\hline Guilty & 39 & 81.3 \\
\hline Total & 48 & 100.0 \\
\hline \multicolumn{3}{|l|}{ Sentence } \\
\hline None & 8 & 16.7 \\
\hline Time Served + Probation & 6 & 12.5 \\
\hline 11 - 36 Months in Prison & 14 & 29.2 \\
\hline 3 - 40 Years in Prison & 16 & 33.3 \\
\hline Life in Prison & 4 & 8.3 \\
\hline Total & 48 & 100.0 \\
\hline
\end{tabular}


premeditated and malicious murder) that the Prosecutors wanted to find them guilty of, therefore necessitating more court actions, as further explained in the next section on the court proceedings used in this jurisdiction.

Court proceedings. Thirty three percent of the cases involved a negotiated plea bargain between the defense and prosecuting attorneys. Thirteen percent of the cases ended in an open plea bargain (the defense attorney tells the prosecuting attorney that their client admits to the homicide to a certain degree and the prosecuting attorney agrees to the charges). Overall then, $46 \%$ of the cases ended in some kind of plea bargain agreement.

Seventeen percent of the cases required a degree of guilt hearing. This means that the client admitted to committing the homicide but did not admit to the degree of homicide the prosecutors were charging the defendant with in the courts. In other words, there is a level of disagreement between the prosecuting and defense attorneys as to the level of malice and premeditation involved in the homicide. Their differences cannot be resolved so they have a hearing before a judge to determine the appropriate degree of homicide for the defendant to be charged under. First-degree homicide is a capital offense in the state where the data was collected for this study. As a result, the defense attorneys are likely very eager to get homicide charges dropped to a lower degree as their first course of action, if at all possible.

Another $27 \%$ of the cases were resolved with a bench trial and only $6 \%$ (3 cases) took the option of a jury trial. Two cases were dropped at some point during the court proceedings due to new exculpatory evidence.

Adjudication. Eighty one percent of the cases were adjudicated guilty, whereas only $10 \%$ were found to be not guilty. Four of the cases were dropped.

Sentence. Out of the 48 cases, 40 resulted in some kind of sentence. Thirty three percent of the forty-eight defendants received a prison sentence of somewhere between 3 - 40 years. Eight percent received a sentence of life in prison. Twenty nine percent of the cases ended with a sentence of 11 - 36 months in prison. Also, $13 \%$ of the women were given time served (meaning no additional prison time after being held from arrest to court proceedings) plus probation.

Table 2 provides results for the female homicide defendants' age, race, previous criminal history and previous history of abuse.

Age. The ages of the female defendants ranged from an 11-year-old who was charged as an adult to 58 years of age. The average age of the women was 29 , the mode was 23 and the median age was 26.5 years old.

Race. In this sample there were 9 White, 37 African American, and 2 Hispanic female homicide defendants.

Criminal history. For the three measures of the female homicide defendant's criminal records that were recorded, $54 \%$ had previous arrests on their records, and $40 \%$ had previously been convicted for some kind of crime. Only $25 \%$ had previous criminal convictions for a violent offense.

History of abuse. History of abuse in childhood or by the homicide victim is 
Table 2. Descriptive Statistics for Homicide Defendants.

\begin{tabular}{|c|c|c|}
\hline Variables & $\mathbf{N}$ & Percent \\
\hline \multicolumn{3}{|l|}{ Age } \\
\hline $11-16$ & 2 & 4.2 \\
\hline $17-21$ & 8 & 16.7 \\
\hline $22-29$ & 18 & 37.5 \\
\hline $30-40$ & 13 & 27.1 \\
\hline $41-50$ & 7 & 14.6 \\
\hline Total & 48 & 100.0 \\
\hline \multicolumn{3}{|l|}{ Race } \\
\hline White & 9 & 18.8 \\
\hline African American & 37 & 77.1 \\
\hline Hispanic & 2 & 4.2 \\
\hline Total & 48 & 100.0 \\
\hline \multicolumn{3}{|l|}{ Previous Arrest Record } \\
\hline Yes & 26 & 54.2 \\
\hline No Total & 2248 & 45.8100 .0 \\
\hline \multicolumn{3}{|c|}{ Previous Criminal Conviction } \\
\hline Yes & 19 & 39.6 \\
\hline No & 29 & 60.4 \\
\hline Total & 48 & 100.0 \\
\hline \multicolumn{3}{|c|}{ Previous Violent Crime Conviction } \\
\hline Yes & 12 & 25.0 \\
\hline No & 36 & 75.0 \\
\hline Total & 48 & 100.0 \\
\hline \multicolumn{3}{|c|}{ History of Childhood Sexual Abuse } \\
\hline Yes & 26 & 29.7 \\
\hline No & 11 & 70.3 \\
\hline Total & 37 & 100.0 \\
\hline \multicolumn{3}{|c|}{ History of Childhood Physical Abuse } \\
\hline Yes & 24 & 66.7 \\
\hline No & 12 & 33.3 \\
\hline Total & 36 & 100.0 \\
\hline \multicolumn{3}{|c|}{ History of Physical Abuse by Homicide Victim } \\
\hline Yes & 19 & 40.4 \\
\hline No & 28 & 59.6 \\
\hline Total & 47 & 100.0 \\
\hline \multicolumn{3}{|l|}{ BWS } \\
\hline Yes & 16 & 44.4 \\
\hline No & 20 & 55.6 \\
\hline Total & 36 & 100.0 \\
\hline
\end{tabular}


missing data for some cases because some homicide defendants refused to have the examination by the Forensic Psychiatrist that is automatically provided for each defendant in the Homicide Division of the Public Defender's Office. As a result, take note of the fact that there is incomplete data in this sample regarding the defendants' histories of childhood physical abuse, childhood sexual abuse, and physical abuse by the homicide victim. Nevertheless, we do have data on at least $75 \%$ of the overall cases for each of these variables. Taking these missing cases into consideration, results displayed in Table 2 indicate that $67 \%(\mathrm{n}=36)$ of the women reported being physically abused as a child, and $70 \%(\mathrm{n}=37)$ reported childhood sexual abuse in their personal history. Further, $40 \%(n=47)$ of the female homicide defendants reported there was a history of physical abuse by the victim of the homicide (or this was ascertained during data collection because there was police record of previous violence-related calls that involved the homicide victim and defendant).

Battered Woman's Syndrome. Of the 48 women in the sample, $44 \%$ were diagnosed with BWS by the Forensic Psychiatrist $(\mathrm{n}=36)$. The remaining 12 did not get a diagnosis from the Forensic Psychiatrist, so it is unknown if BWS was an issue for them.

In Table 3, we present results on the homicide victims and the female homicide defendants' relationship to the victims.

Relationship to victim. In this sample of 48 female homicide defendants, $29 \%$ of the victims were their boyfriend or husbands, $6 \%$ were their ex-boyfriends or ex-husbands, and 38\% were friends or acquaintances of some kind. Further, $17 \%$ of the homicide victims in these cases were strangers, $8 \%$ were their own child, and $2 \%$ were some other kind of family member.

Age. The homicide victims ranged in age from six-months to 91 years old. The average age of the victims was 39.5 and the median age of the victims was 37.

Race. Seventy five percent of the victims were African American, 19\% were White, $4 \%$ were Hispanic, and $2 \%$ were Asian.

Sex. Seventy nine percent of the victims were males. Only ten of the 48 victims were females.

The data was further analyzed to determine the significance of the different variables. Chi-Square tests of significance were used.

Race. The cross-tabulation indicated that of the nine White defendants in the sample, five received a sentence of only 11 - 36 months, one received only time served, and three received no jail or prison sentence at all. Yet, of the 33 African American defendants, only five received no sentence, only four received time served, and only 9 received a light sentence of 11 - 36 months. A full 15 of the 33 African American defendants received a sentence of between 3 - 40 years and four received life sentences. None of the White defendants received a life sentence or a sentence over 3 years in prison. The chi-square tests (two tailed) revealed that there was no statistically significant difference in the length of the 
Table 3. Descriptive Statistics for Homicide Victims.

\begin{tabular}{|c|c|c|}
\hline Variables & $\mathbf{N}$ & Percent \\
\hline \multicolumn{3}{|c|}{ Relationship to Homicide Defendant } \\
\hline Boyfriend/Husband & 14 & 29.2 \\
\hline Ex-boyfriend/Ex-husband & 3 & 6.3 \\
\hline Friend/Acquaintance & 18 & 37.5 \\
\hline Child & 4 & 8.3 \\
\hline Stranger & 8 & 16.7 \\
\hline Other Family Member & 1 & 2.1 \\
\hline Total & 48 & 100.0 \\
\hline \multicolumn{3}{|l|}{ Age } \\
\hline $0-10$ & 4 & 8.3 \\
\hline $11-16$ & 0 & -- \\
\hline $17-21$ & 3 & 6.3 \\
\hline $22-29$ & 10 & 20.8 \\
\hline $30-40$ & 11 & 22.9 \\
\hline $41-50$ & 6 & 12.5 \\
\hline $51-60$ & 6 & 12.5 \\
\hline $61-80$ & 8 & 16.7 \\
\hline Total & 48 & 100.0 \\
\hline \multicolumn{3}{|l|}{ Race } \\
\hline White & 9 & 18.8 \\
\hline African American & 36 & 75.0 \\
\hline Hispanic & 2 & 4.2 \\
\hline Asian & 1 & 2.1 \\
\hline Other & 0 & -- \\
\hline Total & 48 & 100.0 \\
\hline \multicolumn{3}{|l|}{ Biological Sex } \\
\hline Male & 38 & 79.2 \\
\hline Female & 10 & 20.8 \\
\hline Total & 48 & 100.0 \\
\hline
\end{tabular}

sentence received by the race of the defendant $\left(\mathrm{X}^{2}=12.364 ; p=0.136\right)$. Therefore, although not statistically significant in the chi-square test, a visual inspection of the cross-tabulation revealed mild support for the hypothesis that minority defendants would receive longer sentences than White defendants.

Another cross-tabulation examined the possible relationship between race of the defendant and adjudication of guilt. In the cross-tabulation, 32 of the 37 African American defendants were adjudicated guilty, whereas of the nine White defendants, seven were adjudicated guilty. Yet, it must be taken into considera- 
tion that almost all of the women in this sample were adjudicated guilty and most of the women admitted openly to having committed the homicides in question, so their actual innocence was not in question as much as a fair punishment (degree of homicide to plead guilty to), taking into account the circumstances of the crime and any aggravating and mitigating factors involved. The chi-square test revealed no statistically significant difference between race of defendant and guilty judgment in their case $\left(\mathrm{X}^{2}=5.175 ; p=0.270\right)$, but of course, the sample is very small and made up disproportionately of African American women.

The hypothesis that female defendants with White victims would have received longer sentences than those with Minority victims was also not supported by chi-square results $\left(\mathrm{X}^{2}=6.230 ; p=0.904\right)$. Nobody received the death penalty and four women received life in prison (one with a White victim and three with African American victims). Out of all 48 victims, 36 were African American though (so there was not an equal distribution of race among the victims in this sample due to the demographics of this particular Public Defender's office). Of those cases with Black victims, three resulted in life in prison, twelve resulted in a sentence of somewhere between 3 - 40 years in prison, eleven resulted in a sentence of 11 - 36 months in prison, and four resulted in time served plus a period of probation. There were nine White victims overall in the cases examined for this study: one resulted in a sentence of life in prison, two resulted in sentences of 3 - 40 years in prison, three resulted in a sentence of $11-36$ months in prison, and one resulted in time served plus a period of probation. For the two Hispanic homicide victims in the cases examined, one resulted in time served and one resulted in a sentence of somewhere between 3 and 40 years of prison time. For the single Asian homicide victim the case resulted in a sentence of 3 40 years.

Age. Due to the idea that young people are less socially integrated than adults and therefore their crimes will likely have a large quantity of law applied, in Black's view, it was hypothesized that youthful homicide defendants would receive longer sentences than older defendants. Chi-square results revealed no statistically significant difference in the sentence received by defendant's age $\left(\mathrm{X}^{2}=\right.$ $18.653 ; p=0.287$ ) and an examination of the cross-tabulations did not reveal any interesting patterns.

It was also expected that homicide defendants accused of killing either a child or an elderly person would receive harsher sentences than those accused of killing somebody in the middle age groups, but no evidence of this was suggested in the chi-square test $\left(\mathrm{X}^{2}=22.701 ; p=0.537\right)$ and the cross-tabulation revealed no discernable pattern of difference either.

Relationship to victim. It was suggested that due to the close relational distance between intimates in a relationship, female defendants accused of killing an intimate partner would receive lighter sentences than those found guilty of killing strangers or others. The chi-square test reveals that there was a statistically significant difference in the severity of the sentence by the relationship of 
the defendant to the victim $\left(\mathrm{X}^{2}=31.638 ; p=0.047\right)$. The only cases that resulted in a life sentence were those in which the victim was a friend or acquaintance (two cases) and one case in which the victim was a stranger to the homicide defendant. Results indicate that those accused of killing a boyfriend or husband did receive the lightest sentences overall: only two resulted in a prison sentence of 3 40 years, nine cases resulted in a sentence of only 11 - 36 months in prison, two resulted in a sentence of time served plus probation, and one received no jail or prison time at all. No woman adjudicated guilty for the murder of her boyfriend or husband received a life sentence in prison.

Interviews with the Public Defenders corroborate this finding. They highlight the importance of the relationship between the victim and offender in the handling of homicide cases. One of the Public Defenders explained why homicides involving strangers tend to result in harsher charges and sentences.

If it's, I think, a stranger... any time a stranger is killed, I think that's always more of a disturbing element not just to society but to prosecutors as well. And you have to do that much more work to mitigate the case and to say ok... because you don't want someone walking around who's just going to go off and kill somebody that they don't know...

Battered woman syndrome diagnostic: The chi-square test showed that those diagnosed with BWS did receive lighter sentences than those without BWS diagnoses $\left(\mathrm{X}^{2}=14.400 ; p=0.006\right)$. For instance, no defendant with BWS received a sentence of life in prison and only four received a sentence of 3 - 40 years in prison, compared to those without BWS, of whom eight received a 3 - 40 year harsh sentence.

Despite the statistically significant finding described above, the hypothesis that female defendants accused of killing their intimate partner and diagnosed with BWS would receive lower sentences than those accused of killing someone in other circumstances did not receive statistical support in the chi-square test, although the results did approach statistical significance (no BWS: $\mathrm{X}^{2}=25.534 ; p$ $=0.182$ ); (diagnosed with BWS: $\mathrm{X}^{2}=12.107 ; p=0.060$ ). (Remember that the number of cases in this test is limited to 36 since some women were not given psychiatric examinations and some legal cases included in this study did not result in a sentence). It is important to note that 10 out of the 16 women who killed their intimate partners were diagnosed with BWS. Further, of those 10 women, 8 of them received only 11 - 36 month sentences. For those defendants without a BWS diagnosis, eight received a 3 - 40 year sentence and three received a sentence of life in prison. The three women who received life sentences had each killed a friend or acquaintance, yet none of the women who killed a current or ex-intimate partner received such a lengthy sentence.

Public Defenders frequently commented on the previous experience of Prosecutors in charging domestic violence abusers. In other words, Prosecutors early in their careers, usually start out prosecuting petty crimes. After gaining experience, they are assigned more serious crimes such as burglaries or grand larce- 
nies. Only after many years of experience, are they given the responsibility to prosecute violent crimes like rapes and domestic violence assaults. However, it is ironic that by the time they have gained enough experience to prosecute homicide cases, they have already spent years as victims' advocates in their role of prosecuting rapists and intimate partner abusers.

Well I think that the loved one... if there's evidence that the "loved one" (gestures air quotes) was an abuser I think that the prosecutors tend to view that in a different way. A lot of homicide prosecutors cut their teeth in "special victim's units" (gestures air quotes) and have been defenders of battered women, who've seen themselves as defenders of battered women for many, many years, so they do have some more maybe sensitivity when a woman kills in that context, and I think that they're prosecuting the abusers time and time and time again. I think that ends up affecting the way that they, you know, it's again that disconnect in terms of humanization. I think that prosecutors maybe are better able to humanize a long-time victim of domestic abuse because that was their victim for years and years and years before they became homicide prosecutors.

Other Public Defenders emphasized the importance of demonstrating to the Court the context of the homicide and the immediate danger perceived by women in these BWS cases. Not only is the prior relationship important, it is necessary to establish the quality of the prior relationship between the victim and offender.

The thing is, especially with most of the women cases, you have this abuse thing going on so that prior relationship is really important to see. The way you try these cases... it's just not that particular moment. In self-defense you have to be able to go into their mind and the jury has to know everything they know to determine whether what they did was reasonable under the circumstances. If they don't know that this thing happened and the guy slaps her and does everything else, if they don't know that that's how it starts out a lot of the times before they were beaten and tortured and all this other shit, you've got to realize what's reasonable if she's doing that knowing what's coming next versus he just hit her once. They've got to know all that. They have to know everything she knows to determine why she did it. From that standpoint that's important.

It was further suggested that due to courtroom workgroup understanding of feminist explanations of female violent crime and due to the close relational distance between victim and alleged offenders, it was likely we would find that those who were physically abused by the homicide victim prior to the fatal incident would receive lower sentences than those who had no history of abuse by the victim. In this sample, 19 of the homicide defendants had been physically abused by the victim of their homicide at some point prior to the fatal incident. Yet, interestingly, three of those cases involved a friend or acquaintance and one 
involved the murder of a relative. Nevertheless, the original hypothesis about this issue was not supported by the analysis. The chi-square test indicated a statistically insignificant difference in the sentence received depending upon whether or not the alleged perpetrator had a history of being physically abused by the homicide victim $\left(\mathrm{X}^{2}=6.726 ; p=0.151\right)$.

\section{Discussion}

It is important to emphasize the fact that not all the women diagnosed with BWS in this sample actually ended up killing a former or current intimate partner. Three of the women diagnosed with BWS killed a friend or acquaintance, and two killed complete strangers. This unexpected result suggests that the impact of BWS, or histories of physical or sexual abuse, can extend out to relationships and interactions with others in lethal ways, not just intimate partners. However, on closer analysis, it becomes clear that several of the women were physically or sexually abused (or threatened at the time of the fatal incident) by someone other than a current or former intimate partner. For instance, one woman was being physically abused by her cousin at the time of the incident, one woman was being threatened sexually by a male friend at the time of the fatal incident, and another woman was being forced to engage in sexual acts she did not want to during an interaction with a John while working as a prostitute. In sum, for the cases in this sample, the impacts of physical and sexual abuse extended beyond relationships with current or former intimates. And the intersections of race, class, and sex and gender power differentials are quite clear when the specific details of the relationships and circumstances surrounding these tragic homicides are examined in their full context.

Overall, this study lends support to the Blackian theory of law in that homicide cases between intimate partners tended to attract less law (in the form of shorter sentences) than lethal crimes committed by women against those in less close relationships to themselves, such as strangers and acquaintances.

Further, our findings do conform to earlier research findings that female homicide offenders in America are overrepresented by African Americans (Goetting, 1988; Mann, 1987; Weisheit, 1984). This study found that $67 \%$ of the women reported physical abuse as a child, which also conforms to disproportionately high records of victimization (incest, rape, battering) of female offenders found in previous research (Fletcher, Shaver, \& Moon, 1993; Belknap \& Holsinger, 1998). Our sample contradicts the feminist assumption that most female perpetrated homicides are committed against intimates (since in this sample $32 \%$ of the victims were current or former boyfriends or husbands, whereas 38\% were friends or acquaintances). Yet, domestic altercations did describe the situation behind most of the homicides in this sample (31\%). It is also important to note that several of the women who were diagnosed with BWS were accused of killing not a current or former intimate partner, but somebody else such as a relative, acquaintance, or even their own child. 
The hypothesis that female homicide defendants accused of killing an intimate partner would receive more lenient sentences than those accused of killing a stranger or acquaintance was supported. Also, the hypothesis that those women diagnosed with BWS would receive lighter sentences than those women without such a diagnosis was supported. Several Public Defenders in this study emphasized that they, as well as Prosecutors, have a heightened sense of empathy for women who have killed an abusive partner. This empathy, perhaps leads to lighter charges and sentences, especially for BWS cases.

I think really if you have an abused woman prosecutors are more, because they do those cases, they do the cases where the guys are charged for abuse and things, so they understand what that can be so they're a little more sympathetic to that than they are to some other kind of defense.

It should be noted, however, that the hypothesis that defendants accused of killing an intimate partner who were also diagnosed with BWS would receive lighter sentences than those without the diagnosis, did approach statistical significance, but did not receive strong statistical support in our analysis. The results of the data analysis presented in this study also lent mild support to the idea that African American women would be subject to more law than White defendants. In regards to this study's other hypotheses, none of the other measures proved statistically significant.

\section{Limitations}

The sample used for this study consists of a small number of cases in only one large city in the Mid-Atlantic region; therefore, the results are not generalizable to overall patterns of female perpetrated homicides and court proceedings across the United States. Several assumptions of Chi-square analysis are violated, including the need for a large and random sample, yet this is often the case with the use of Multiple Regression and other tests of significance used by Social Scientists. Yet, the Chi-square analyses are not as important as the picture gleamed by the results of the cross-tabulations and qualitative interviews in this research. In the future, larger samples of female homicide cases should be collected and analyzed to gain further insight into the research began by our modest effort so that tests of significance can have more meaning. Unfortunately, there are no national level data sources such as the Uniform Crime Reports which provide the variables examined in this research for analysis.

Further, most spousal homicides of both males and females take place in rural regions of the United States (U.S. Department of Justice, 2011) but this sample consists largely of African American homicide defendants living in an inner city context who needed to rely upon a Public Defender for their case. This means that our sample is mainly a sample of lower-class, urban, minority women whose homicidal behavior likely differs in complex and obvious ways from the women in this same city of higher socioeconomic status who have during that same time period of 1994-2011 been accused of murder and then retained a private attor- 
ney to handle their case. This study does not include data on middle class or upper status women arrested for homicide and defended by a private attorney, so there is no way to draw overall conclusions about the outcomes of all female homicide cases in this jurisdiction. Keep in mind also, that due to the overall small sample, low cases in some categories of the cross-tabulations wherein the Chi-square tests were performed made it difficult to achieve statistical significance, even in those cross-tabulations where there seemed to be a visibly obvious pattern of difference between categories. A larger, nationally representative sample of court data would yield the most reliable statistical results, but such secondary data on the variables of interest for this study are not currently available.

There is no way to control for the socio-economic status of the women or the victims of homicide in this study. It can be assumed that since these women were clients of a Public Defender's office in a large city, they likely are of a low socio-economic class and so likely too are the victims, but there is no variable to confirm this in the data collected for this study. That is, the data collection for this study did not include variables such as income, education, or employment status/occupation of either the victims or offenders due to time constraints in the extremely laborious and time-consuming data collection process, which required the valuable. Overall, this study supports the Blackian theory of law that homicide cases between intimate partners tended to attract less law than lethal crimes committed against those at a greater social distance from the perpetrator, such as strangers or time, and assistance of the Chief Homicide Defense Attorney. Further, some of the data is self-report data by the homicide defendants who were interviewed by a Forensic Psychiatrist, upon referral to the Public Defender's Office. Therefore, the information provided by the accused, which led to the diagnoses of BWS by the Forensic Psychiatrist may be subject to misinformation, exaggeration, or recall problems. (Although, the Public Defender's Office would also go to great lengths to support any allegations of previous abuse or trauma by having a Mitigation Specialist research each and every homicide defendant, essentially creating a full Life Course profile of the defendants and their past histories.) Lastly, another limitation with the data used in this study is that the women's versions of what took place at the time of the homicide were often taken from their interviews with police and/or the Public Defenders themselves. There is a possibility that some of the women may have provided false information or exaggerated in an attempt at their own defense.

\section{Conclusion}

The results reveal that women who killed a boyfriend or husband received lighter sentences than those who killed a stranger or acquaintance. Overall, this study supports the Blackian theory of law that homicide cases between intimate partners tended to attract less law than lethal crimes committed against those at a greater social distance from the perpetrator, such as strangers or acquaintances. This study also concludes that women diagnosed with BWS received 
lighter sentences than women without such a diagnosis. This study opens up questions for future research, which specifically have to do with the racial background of the defendant and the length of sentence. Though the cross-tabulation indicates a mild support for the hypothesis that minority defendants would receive longer sentences than White defendants, we have not been able to establish statistical significance in the length of the sentence received by the race of the defendant. We propose this as an area for future research. Black's propositions on directionality and distance can be used to further explain the issue of intimate partner homicide sentencing and the racial background.

Overall, this research highlights the importance of examining on a larger scale the issues of female victimization and its link to PTSD, BWS, and subsequent violent or criminal behavior as a result. This research highlights the importance of abuse in explaining female perpetrated violence, and it also makes clear the commonalities that many homicidal women share in their traumatic pasts. From a feminist perspective, it is noteworthy that even in this small sample in one jurisdiction, most of the women accused of homicide had been physically and/or sexually abused as children, and many of the women had been victims of violence at the hands of the person they ended up killing (usually a man, and usually an intimate partner).

In conclusion, from a social scientific policy perspective, this research suggests that more prevention of female physical and sexual victimization could have prevented the murders examined in this study from ever happening. Combining both Black's theory of law and a feminist view provides deeper insight into the importance of the quality and social distance of a relationship between victim and offender in predicting the handling of a homicide case by our legal system. From a feminist viewpoint, it is reassuring that the importance of prior physical and sexual abuse of the victim by someone she knows and loves is taken into account and that in cases of intimate partner violence related homicides, the courts in this jurisdiction seem to be sympathetic to the women's plight when they find themselves fighting back for their lives.

\section{References}

Auerhahn, K. (2006). Conceptual and Methodological Issues in the Prediction of Dangerous Behavior. Criminology and Public Policy, 5, 801-808. https://doi.org/10.1111/j.1745-9133.2006.00411.x

Bannister, S. A. (1991). The Criminalization of Women Fighting Back against Male Abuse: Imprisoned Battered Women as Political Prisoners. Humanity and Society, 15, 400-416.

Belknap, J. (2000). The Invisible Woman: Gender, Crime and Justice. Belmont, CA: Wadsworth.

Belknap, J., \& Holsinger, K. (1998). An Overview of Delinquent Girls: How Theory and Practice Failed and the Need for Innovative Changes. In R. T. Zaplin (Ed.), Female Offenders. Critical Perspectives and Effective Interventions. Gaithersburg, MD: Aspen Publishers.

Black, D. (1976). The Behavior of Law. New York: Academic Press. 
Black, D. (1989). Sociological Justice. New York: Oxford University Press.

Browne, A. (1987). When Battered Women Kill. New York: Free Press.

Campbell, J. C. (1992). If I Can't Have You No One Can: Power and Control in Homicide of Female Partners. In J. Radford, \& D. H. Russell (Eds.), Femicide: The Politics of Woman Killing (pp. 99-113). New York: Twayne.

Chimbos, P. (1976). Marital Violence: A Study of Interspouse Homicide. In K. Ishwaran (Ed.), The Canadian Family (2nd ed.). Toronto: Holt, Rinehart and Winston.

Dawson, M. (2006). Intimacy and Violence: Exploring the Role of Victim-Defendant Relationship in Criminal Law. Journal of Criminal Law and Criminology, 96, 1417-1450.

DeKeseredy, W., \& Hinch, R. (1991). Woman Abuse: Sociological Perspectives. Toronto: Thompson Educational Publishing.

Easteal, E. (1993). Killing the Beloved: Homicide between Adult Sexual Intimates. Canberra: Australian Institute of Criminology.

Ewing, C. (1987). Battered Women Who Kill: Psychological Self-Defense as Legal Justification. Lexington, MA: Lexington Books.

Fletcher, B. R., Shaver, L. D., \& Moon, D. G. (1993). Women Prisoners: A Forgotten Population. Westport, CT: Praeger.

Gange, P. (1998). Battered Women's Justice: The Movement for Clemency and the Politics of Self-Defense. London: Prentice Hall.

Gillespie, C. (1989). Justifiable Homicide. Columbus, OH: Ohio State University Press.

Goetting, A. (1987). Homicidal Wives: A Profile. Journal of Family Studies, 8, 332-341. https://doi.org/10.1177/019251387008003006

Goetting, A. (1988). Patterns of Homicide among Women. Journal of Interpersonal Violence, 3, 3-20. https://doi.org/10.1177/088626088003001001

Goetting, A. (1999). Getting out. Life Stories of Women Who Left Abusive Men. New York: Columbia University Press.

Hadley, J. (1992). A Study of Women Imprisoned for Homicide (pp. 1-20). Forsyth, GA: Georgia Department of Corrections.

Heidensohn, F. (1985). Women and Crime. New York: New York University Press.

Hephner, S. (2002). Negotiation: The Strength of the Courtroom Workgroup and the Guilty Plea Process. Huntsville, TX: Sam Houston State University.

Kirkwood, D. (2003). Female Perpetrated Homicide in Victoria between 1985 and 1995. Australian and New Zealand Journal of Criminology, 36, 152-172. https://doi.org/10.1375/acri.36.2.152

Knepper, P., \& Barton, S. (1997). The Effect of Courtroom Dynamics on Child Maltreatment Proceedings. Social Science Review, 71, 288-308.

Kruttschnitt, C. (1982). Respectable Women and the Law. The Sociological Quarterly, 23, 221-234. https://doi.org/10.1111/j.1533-8525.1982.tb01009.x

Leonard, E. D. (2001). Convicted Survivors: Comparing and Describing California's Battered Women Inmates. The Prison Journal, 81, 73-86.

https://doi.org/10.1177/0032885501081001006

Leonard, E. D. (2002). Convicted Survivors. The Imprisonment of Battered Women Who Kill. New York: State University of New York Press.

Lloyd, A. (1995). Doubly Deviant, Doubly Damned: Society's Treatment of Violent Women. New York: Penguin Books.

Mann, C. R. (1987). Black Women Who Kill. In R. L. Hampton (Ed.), Violence in the 
Black Family (pp. 157-186). Lexington, MA: Lexington Books.

O’Keefe, M. (1997). Incarcerated Battered Women: A Comparison of Battered Women Who Killed Their Abusers and Those Incarcerated for Other Offenses. Journal of Family Violence, 12, 1-19. https://doi.org/10.1023/A:1021989732032

Osthoff, S. (1991). Restoring Justice: Clemency for Battered Women. Response, 14, 2-3.

Polk, K. (1994). When Men Kill: Scenarios of Masculine Violence. Cambridge: Cambridge University Press.

Roberts, A. R. (1996). Battered Women Who Kill: A Comparative Study of Incarcerated Participants with a Community Sample of Battered Women. Journal of Family Violence, 11, 291-304. https://doi.org/10.1007/BF02336946

Shaw, M., \& Dubois, S. (1995). Understanding Violence by Women: A Review of the Literature. Ottawa: Correctional Services of Canada.

Totman, J. (1978). The Murderess. A Psychosocial Study of Criminal Homicide. San Francisco, CA: R and E Research Associates.

U.S. Department of Justice (2011). Intimate Violence in the United States. https://www.bjs.gov/content/pub/pdf/ipvus.pdf

Walker, L. (1989). Terrifying Love. New York: Harper and Row Publishers.

Walker, L. (2006). Battered Woman Syndrome: Empirical Findings. Annals of the New York Academy of Sciences, 1087, 142-157. https://doi.org/10.1196/annals.1385.023

Weisheit, R. A. (1984). Women and Crime: Issues and Perspectives. Sex Roles, 11, 567581. https://doi.org/10.1007/BF00288111

Young, A. (1996). Imagining Crime: Textual Outlaws and Criminal Conversations. London: Sage.

\section{Submit or recommend next manuscript to SCIRP and we will provide best service for you:}

Accepting pre-submission inquiries through Email, Facebook, LinkedIn, Twitter, etc. A wide selection of journals (inclusive of 9 subjects, more than 200 journals) Providing 24-hour high-quality service User-friendly online submission system Fair and swift peer-review system Efficient typesetting and proofreading procedure Display of the result of downloads and visits, as well as the number of cited articles Maximum dissemination of your research work

Submit your manuscript at: http://papersubmission.scirp.org/ Or contact aasoci@scirp.org 